\title{
An investigation on the comprehension of Persian passives in typical development and autism*
}

\author{
Anna Gavarró \\ Universitat Autònoma de Barcelona. Departament de Filologia Catalana \\ anna.gavarro@uab.cat \\ Yalda Heshmati \\ Columbia University. Teachers College \\ yaldahesh@gmail.com
}

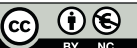

Received: May 15, 2014

Accepted: October 7, 2014

\begin{abstract}
Autism Spectrum disorders have attracted the attention of many researchers working on communicative and pragmatic competence, but much less attention has been paid to the investigation of narrow syntax in this condition. On the other hand, in the field of acquisition, passive sentences (and related constructions) are known to be a late acquisition, and have been argued to be a case of late maturation. In this paper we report results on the comprehension of passive sentences in Persian-speaking children with typical development and with Autism Spectrum Disorders. In our findings, not all ASD children perform in the same way, rather those considered to be high-functioning perform like the typically developing, and the low-functioning have a clearly poorer performance. These results shed some light on former studies (Perovic et al. 2007, Terzi et al. 2014), with seemingly inconsistent results due to the fact that heterogeneous populations were tested.
\end{abstract}

Keywords: passives; comprehension; acquisition; Autism Spectrum Disorders; Persian.

Resum. Una investigació sobre la comprensió de les passives del persa en casos de desenvolupament típic i d'autisme

Els desordres d'espectre autista han interessat molts investigadors de la competència comunicativa i pragmàtica, però no s'ha parat gaire atenció a l'estudi de la sintaxi estricta d'aquesta condició. Per altra banda, en l'àmbit de l'adquisició, s'ha observat que les oracions passives (i construccions relacionades) s'adquireixen tard i s'ha proposat que són un cas de maduració tardana. En aquest

* The authors would like to genuinely thank Mr. Zojaji, founder of the Autism Children Charity Foundation, for his support, and all participants for their willingness to take part in our experiment. We have greatly benefited from discussion with Fatemeh Nemati and from the suggestions of an anonymous reviewer. We also wish to thank Anna Espinal and Ester Boixadera (of the Servei d'Estadística Aplicada at the UAB) for the statistical analysis, and projects FFI2011-29440-C03-03 and 2009SGR 1079 for financial support. The experimental materials were used by courtesy of Kristine Jensen de López and Kenneth F. Drozd. The artist Justyna Kamykowska reserves the copyright of the drawings. 
article descrivim els resultats d'un experiment de comprensió de les oracions passives en nens parlants del persa amb desenvolupament típic i amb autisme. Les nostres investigacions mostren que no tots els nens autistes tenen el mateix comportament: mentre que els nens autistes amb elevada funcionalitat obtenen resultats similars als dels nens amb desenvolupament típic, els nens autistes amb funcionalitat baixa tenen uns resultats clarament pitjors. Aquestes dades aporten una nova perspectiva als estudis previs (Perovic et al. 2007, Terzi et al. 2014), que mostraven resultats aparentment inconsistents a causa de l'heterogeneïtat de les poblacions analitzades.

Mots clau: passives; comprensió; adquisició; autisme; persa.

\begin{aligned} & \multicolumn{2}{c}{ Table of Contents } \\ & 1. Introduction 4. Results \\ & 2. Background 5. How do these results compare with \\ & 3. Persian passives. those in the literature? \\ & Experimental design References \end{aligned}

\section{Introduction}

The acquisition of verbal passive is delayed in numerous languages; amongst them English (Maratsos, Fox, Becker and Chalkley 1985), Spanish (Pierce 1992), Dutch (Verrips 1996), Japanese (Sugisaki 1999), Greek (Terzi and Wexler 2002), Russian (Babyonyshev and Brun 2003) and Catalan (Parramon 2009). Some authors have argued that this late comprehension of passives can be attributed to their sparse presence in the input: in many languages of the world passives are uncommon in colloquial speech and thus in child-directed speech. Consequently, children get very little exposure to the construction. Such is the argument in Demuth, Moloi and Machobane (2010), who further claim that in languages with more abundant passive production, e.g. Sesotho, children comprehend passives earlier. However, this line of argument is not compelling, due to the fact that child language acquisition exhibits numerous cases of early acquisition of underrepresented structures cases of acquisition under poverty of stimulus (see for instance the acquisition of Slavic multiple interrogatives, very rare in the input; Grebenyova 2011, Gavarró, Lewandowski and Markova 2010). Side by side with these cases, the opposite scenario emerges: constructions which are abundant in the input are late acquisitions in children - this is what Babyonyshev et al. (2001) termed late acquisition under abundance of the stimulus - see the example provided in the same paper on the Russian genitive of negation. Given these findings, compounded with some empirical problems with the research on Sesotho (see Crawford 2008), maturation has been hypothesised to be the source of the late comprehension of passives, whether maturation of A-chains (Borer and Wexler 1992), maturation of thetatransmission (Fox and Grodzinsky 1998), maturation of the properties of defective phases (Wexler 2004), or maturation of the mechanisms regulating intervention (Orfitelli 2012). Of these theoretical approaches, Borer and Wexler (1992) has 
been recast in Wexler (2004), motivated by some theory-internal modifications as well as the need to generalise the analysis to related constructions (the acquisition of raising in particular). Fox and Grodzinsky's (1998) claims were based on experimental results that have never been replicated. Therefore we focus on the two most recent approaches. Wexler (2004) argues that passive delay follows from the fact that immature grammars define $v$ as a phase, whether defective or not (the Universal Phase Requirement). As a consequence, movement out of defective $v$ (e.g. passive $v$ ) is problematic in immature children. Orfitelli (2012) claims that the source of passive delay stems from intervention effects in those structures with raising of an argument across another, structurally intervening, argument. Both Wexler (2004) and Orfitelli (2012) predict that children will have problems in the comprehension of passives, and discrepancies occur in further empirical predictions of their hypotheses: with monoargumental constructions, Wexler (2004) predicts that delay can occur under specific conditions, while for Orfitelli (2012) monoargumental constructions should not give rise to intervention effects. Since in this paper we only deal with passives, our results do not bear on the debate between the Universal Phase Requirement and the intervention effect analysis. Granting that the comprehension of passives develops in children as a result of maturation, there is another empirical issue that we can start to address: at what age is maturation completed? Earlier work on passives indicated problems in comprehension until age 5 (Borer and Wexler 1992), but later work shows that adult-like behaviour is not attained until at least 6.5 (Hirsch and Wexler 2006, Hirsch 2011).

The age at which maturation of the mechanisms underlying the passive is attained may of course vary in populations subject to developmental linguistic deficits, or perhaps cognitive deficits in general. This line of research was initiated in work on passives in Down's syndrome (Perovic 2006) and continued with Autism Spectrum Disorders (Perovic, Modyanova and Wexler 2007) and William's Syndrome (Perovic and Wexler 2010). In this paper we pursue the work of Perovic and colleagues by looking at passive comprehension in Autism Spectrum Disorders in a language not investigated formerly, Persian.

The paper is organised as follows. In section 2 we characterise Autism Spectrum Disorders (ASD hereafter) and provide the little background on passives in ASD in the literature and detail the questions addressed in our paper. In section 3 we sketch the grammatical properties of Persian relevant for our study and present our experimental design. In section 4 we report the results of our experiment. We draw conclusions in section 5 .

\section{Background}

Autism was first documented in the clinical literature in 1943 and characterised by communicative disorders (Kanner 1943). According to the 1994 definition by the American Psychology Association, autism comprises symptoms in communication, social interaction and behavioural patterns (such as stereotyped and repetitive behaviour). Since 2013 Autism Spectrum Disorders include Asperger's syndrome (APA 2013), although the literature does not attribute the individuals with 
Asperger's syndrome any linguistic disorder, and we do not consider any subject with this diagnosis in our paper.

Often ASD individuals are divided into groups according to their cognitive capacities; they also present a wide spectrum of linguistic abilities: while some appear to have a profound linguistic disability and are quasi mute, others appear to develop full linguistic abilities. Given that communicative disorders are central to ASD, research has focused on the pragmatic capacity of ASD subjects (see, amongst others, Lee, Hobson and Chiat 1994, Baron-Cohen, Tager-Flusberg and Cohen 2000, Tager-Flusberg 2001). The results of this research point to problems in turn-taking, literal interpretation of idioms, irony and metaphors, in interpreting the mental states of other individuals (Theory of Mind), and in deixis.

Much less is known about the strictly linguistic competence of ASD. Some phonological deficits have been identified, in particular in the production of intonational contours, since they are often stereotyped and monotone (McCann and Peppé 2003). There are some shared characteristics of ASD and another developmental disorder, Specific Language Impairment (see Leyfer et al. 2008), although the similarities may not hold for the whole population (for example, non-word repetition is a clinical marker of SLI and is also found in some ASD children, but not all, Kjelgaard and Tager-Flusberg 2001). Recently, Perovic, Modyanova and Wexler (2013) identified difficulties in the interpretation of reflexives (in contrast to many other populations, e.g. young children and Broca's aphasics, whose problems, if any, occur with pronouns but not reflexives). This led them to conclude that ASD individuals are not simply delayed but impaired in their linguistic abilities. Two studies have considered the comprehension of passives in ASD: Perovic, Wexler and Modyanova (2007) and Terzi et al. (2014). Since these two studies are the point of reference to our own, we describe them in some detail.

Perovic et al. (2007) considered twelve English-speaking children with ASD (mean age: 11;06, age range 6-17) as well as eight children with Asperger's syndrome (AS) (mean age 13;01) and three control groups for ASD and AS children matched on age, verbal and non-verbal IQ level. The subjects were tested with a two-picture matching task; the experiment included 6 items per sentence type (1).

(1) a. Marge kissed Lisa.

c. Lisa is kissed by Marge.

e. Lisa is kissed. b. Homer loves Bart.

d. Bart is loved by Homer.

f. Bart is loved.

While the children with AS were indistinguishable from the control groups, the ASD children were highly impaired, as witnessed by the results in Table 1. 
Table 1. Percentage of correct comprehension of passives, English, Perovic et al. (2007)

\begin{tabular}{lllllll}
\hline & $\begin{array}{l}\text { actional } \\
\text { active }\end{array}$ & $\begin{array}{l}\text { actional } \\
\text { long pass }\end{array}$ & $\begin{array}{l}\text { actional } \\
\text { short pass }\end{array}$ & $\begin{array}{l}\text { psych } \\
\text { active }\end{array}$ & $\begin{array}{l}\text { psych long } \\
\text { pass }\end{array}$ & $\begin{array}{l}\text { psych short } \\
\text { pass }\end{array}$ \\
\hline ASD & $78 \%$ & $36 \%$ & $39 \%$ & $67 \%$ & $26 \%$ & $30 \%$ \\
K-BIT controls & $98 \%$ & $88 \%$ & $93 \%$ & $97 \%$ & $65 \%$ & $67 \%$ \\
PPVT controls & $92 \%$ & $82 \%$ & $88 \%$ & $91 \%$ & $55 \%$ & $55 \%$ \\
TROG controls & $96 \%$ & $69 \%$ & $79 \%$ & $89 \%$ & $\% 28$ & $42 \%$ \\
\hline
\end{tabular}

Abbreviations: long pass = long passives; short pass = short passives; psych = psychological verbs. $\mathrm{K}-\mathrm{BIT}=$ Kaufman Brief Intelligence Test; PPVT = Peabody Picture Vocabulary Test; TROG = Test for Reception of Grammar.

Not only their performance was low in psychological passives (e.g. be loved), as found in the English-speaking typically developing children (including those in their experiment), but they also performed poorly on actional passives (e.g. be kissed).

Terzi et al. (2014) considered passives in Greek, a language in which passive interpretation can be rendered with a reflexive verb or a passive verb, illustrated in $(2 \mathrm{a})$ and $(2 \mathrm{~b})$ respectively.

(2) a. O Giorgos skepazete.

the Giorgos cover.3SG.NON-ACT

'Giorgos is being covered.'

b. O papus taizete.

the grandpa feed.3SG.NON-ACT

'Grandpa is being fed.'

The children tested were twenty 5 to 8 year-olds (mean age: 6;06) and twenty age controls. The ASD children were diagnosed using DSM-IV criteria (APA 1994) and ADOS (Autism Diagnostic Observation Schedule, Lord et al. 2000). Importantly, all the ASD children had non-verbal abilities of 80 or above (in the Raven's Coloured Progressive matrices), and therefore were classified as high-functioning.

Children were tested with 6 items per condition (passive verb with passive interpretation, reflexive verb with passive interpretation; we ignore other conditions also tested). The results appear in Table 2.

Table 2. Mean comprehension of passives in percentages (standard deviation in parenthesis), Greek, Terzi et al. (2014) (TD = typically developing)

\begin{tabular}{lll}
\hline & $\begin{array}{l}\text { passive verbs with passive } \\
\text { interpretation }\end{array}$ & $\begin{array}{l}\text { reflexive verbs with passive } \\
\text { interpretation }\end{array}$ \\
\hline ASD children & $66.6 \%(22.9 \%)$ & $93.3 \%(16.6 \%)$ \\
TD children & $70 \%(20 \%)$ & $94.9(8 \%)$ \\
adult controls & $100 \%$ & $100 \%$ \\
\hline
\end{tabular}


The statistical analysis of these results indicated that sentence type had a significant effect on comprehension, with passive verbs being less accurately understood than reflexive verbs, but there were no other effects or interactions - i.e. ASD and TD children did not perform differently. The individual analysis (in terms of number of children with ceiling performance) did not reveal any differences between the two groups of children either. Therefore, the results for Greek sharply contrast with those for English, although there is no contrast between the passive constructions of Greek and English to be attributed with the difference.

Our first goal is thus to attempt to resolve this inconsistency in the results of the two studies, by reference to another language, Persian, and also extend the empirical coverage of linguistic research in ASD. Second, we address the more general question of whether subjects with ASD are impaired in the comprehension of passives and, if so, if their performance is similar to that of immature TD children.

\section{Persian passives. Experimental design}

Persian (also known as Farsi) is a language of the Indo-Iranian branch of the IndoEuropean family. It is an SOV language with a rich verbal inflectional system. Its active/passive alternation is illustrated in (3). ${ }^{1}$

(3) a. Æli Mina ra did.

Ali Mina OM saw.3SG

'Ali saw Mina.'

b. Mina tævæsote Æli did-eh šod.

Mina by Ali seen.PTCP became.3SG

'Mina was seen by Ali.'

As shown in (3a), the object of a transitive verb is marked with $r{ }^{2}$ There is some debate regarding the exact nature of $r a$, as it is obligatory with proper nouns and personal and demonstrative pronouns, but does not appear with unspecific, unidentifiable objects (4), and there is a range of cases in between where ra is optional (in that respect, it differs from well-known cases of differential object marking, such as those of Spanish).

(4) Mæn be foghærā pul(*-ra) mi-dæhæm.

I to poor.PL money(*OM) DUR-give.PRES-1SG

'I give money to the poor.'

1. Abbreviations: $\mathrm{DUR}=$ durative, $\mathrm{EZ}=$ ezafe, $\mathrm{INDF}=$ indefinite, $\mathrm{OM}=$ object marker, $\mathrm{PRES}=$ present, $\mathrm{PTCP}=$ participle, $\mathrm{SG}=$ singular.

2. $R a$ is also a topic marker; in that case, $r a$ may occur with arguments other than direct objects. Notice that, then, two instances of $r a$ may coexist in the same sentence, one as topic marker, one as object marker. 
For a summary of the debate on the correct characterisation of $r a$, see Bohnacker and Mohammadi (2012) and references therein. (3b) illustrates the periphrastic passive of Modern Persian - Old Persian had a morphological passive, now lost. The structure in (3b) consists in an argument that has been raised from object position (and has as a consequence no $r a$ object marker), followed by a past participle and the passive auxiliary šodcen 'to become'. An optional agentive PP precedes the verb (treveesote Ali 'by Ali').

Although there is some controversy about sentences such as (3b), particularly about the status of šodcen (see Karimi 1997, Paul 2004, amongst others), we adhere to the view in Nemati (2013) according to which (3b) is a true verbal passive. The arguments to consider it as such are (i) the demotion of the subject, (ii) the promotion of the object to subject position, and (iii) the morphological change in the verb, from an active form to a past participle, and the merge of šodcen, inflected for person and tense.

Šodcen can be found in other non-verbal constructions, preceded by nominals (5), when šodcen alternates with kæerdoen, a light verb implying agentivity, and adjectives (6). We refer the reader to Nemati (2013) for a unified account of šodcen. The existence of these constructions implies that some sentences with šodcen are adjectival, and not derived by A-movement (in a way similar to English verbal passives, which are homophonous to adjectival passives).

a. Rais kar-e xub-i be u pišnæhad kærd. boss job-EZ good-INDF to him offer did.3SG 'The boss offered him a good job.'

b. Kar-e xub-i (tævæsote rais) be u pišnæhad šod. job-EZ good-INDF (by boss) to him offer became.3SG 'He was offered a good job (by the boss).'

(6) Miz (tævæsote Mina) tæmiz šod.

table (by Mina) clean became.3SG

'The table was cleaned (by Mina).'

An anonymous reviewer points out that passives rarely occur in child-directed speech and colloquial Persian, where impersonal constructions are largely preferred (although there are no quantitative studies to prove this claim). As indicated above, this does not make the situation in Persian different from that in other languages.

\subsection{Experimental design}

There is little research on Persian first language acquisition, or ASD (see, however, Zare et al. 2012, Khosravizadeh, Mahabadi and Taghva 2012). To our knowledge, no work has considered passive comprehension in Persian TD or ASD children, although Family (2009) found šodcen to be one of the earliest light verbs to be used in the spontaneous productions of a Persian-speaking girl whose productions were recorded from age 1;11. In order to test the comprehension of passives in Persian, 
we replicated a picture-sentence matching task designed by Armon-Lotem et al. (submitted) under the auspices of COST Action A33.

The original task was used in a large-scale study with 5-year-old speakers of Catalan, Cypriot Greek, Danish, Dutch, English, German, Lithuanian, Polish, Estonian, Finnish and Hebrew. Children were tested on actives, short passives and long passives; the original experiment balanced items according to gender and half of the items corresponded to female characters, the other half to male characters; since Persian has no grammatical gender, this was ignored in our version of the experiment. Of the original 88 items in Armon-Lotem et al., half were removed due to problems of translation (verbs not having a transitive counterpart in Persian) or cultural appropriateness. The final experiment included 44 items, using a set of 11 verbs (22 active sentences, 11 short passives, 11 long passives), exemplified in (7). This experiment was first reported in Heshmati (2013).

(7) a. Dokhtær-e koochæk madær ra miboosæd. girl-EZ little mom OM kiss.3SG 'The little girl kisses mom.'

b. Madær boosid-eh mi-šævæd. mom kiss-PTCP DUR-become-3SG

'Mom is kissed.'

c. Dokhtær-e koochæk dokhtære bozorg ra nævazeš mi-konæd. girl-EZ little girl big OM stroke DUR-does-3SG 'The little girl strokes the big girl.'

d. Dokhtær-e bozorg tævæsote dokhtære koochæk nævazeš girl-EZ big by girl little stroke mi-šævæd. DUR-become-3SG

'Big girl is stroked by the little girl.'

All verbs used were actional (i.e. involving an agent and a theme in their thematic structure), and the same verbs appeared in active and passive sentences; the verbs included moayene kardcen 'examine', donbal kardcen 'chase', boosidon 'kiss', šane koerdcen 'comb', noeghaši koerdoen 'draw' and 'paint', hol dadcen 'push', bceghcel kcerdcen 'hug', hoeml kcerdcen 'carry', ncevazeš kcerdoen 'stroke', poošandcen 'cover', and eslah kcerdoen 'shave'. ${ }^{3}$ Because of the properties of Persian verbal constructions, only two of these verbs are simple verbs with a morphological passive marker, one is a complex predicate with a morphological passive marker and the rest are complex predicates passivised through alternation of the light verb. Nevertheless, all of them are the result of verbal passivisation, with raising of an object to subject position - the crucial property for comparison with English and Greek to hold.

3. It should be pointed out that we didn't control for the frequency of the Persian verbs used in the experiment and that this may account for some of the results of ASD subjects. 


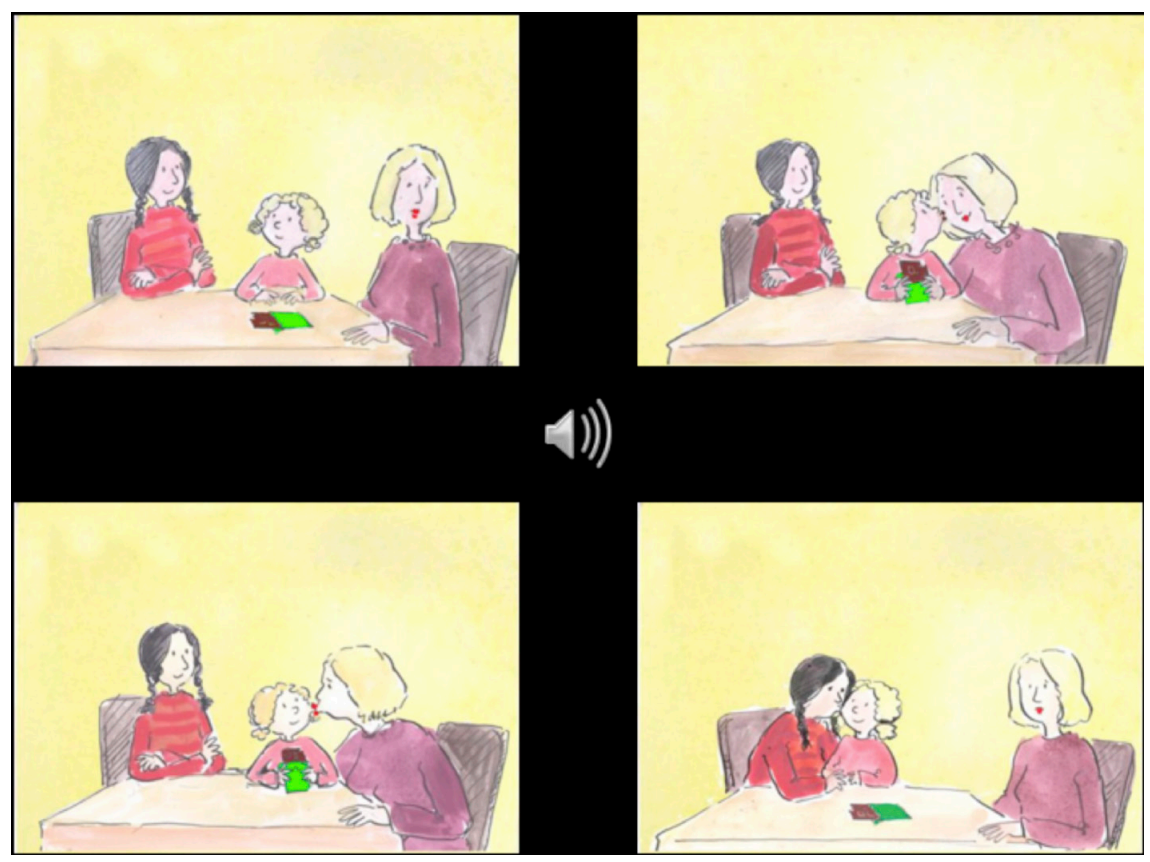

Figure 1. Target picture for (7a) is on the top right.

For each experimental item the child had to choose from a set of four pictures in a screen: one corresponding to the sentence heard, one corresponding to the reverse action (where agent and theme had been exchanged), one with the same action performed by another character and one with no action portrayed. The target pictures were balanced across positions in the screen. All pictures involved three characters, so that mention of two of them was pragmatically felicitous (see O'Brien, Grolla and Lillo-Martin 2006). Crucially, only sensitivity to the linguistic input allows the subject to identify the correct picture. The materials are illustrated in Figure 1.

The order of presentation of the 44 experimental items was randomised into two orders: 1 to 44 and the opposite, 44 to 1 . A full relation of the experimental items can found in the appendix. ${ }^{4}$

\subsection{Subjects}

Given the lack of any study on the acquisition of passives in Persian TD children, we ran our experiment with a group of 10 TD children ( 7 girls and 3 boys) from

4. An anonymous reviewer judged sentence 41 ill-formed without a PP complement, and expressed some doubts on sentences 28 and 32 . These judgments contrast with those of the second author. We can only add that the results for these three items are not different from those for the other experimental items, and that adults performed at ceiling with all of them. 
Tehran, and 10 healthy adult controls. Although, as we will see, the children were slightly older than in the cross-linguistic study of Armon-Lotem et al. (submitted) the results we obtained still allow for a comparison. The ASD children were tested in the Autism Children Charity in Tehran, Iran. Initially fourteen children were to be tested, but four were eliminated from the study due to highly disruptive behaviour; they were all at the low functioning end of the spectrum, and were non-verbal. Ten children ( 1 girl and 9 boys) were finally tested; they had all been diagnosed of ASD based on the DSM-IV (APA 1994). Details of all subjects, all native speakers of Persian, appear in Table 3.

The ASD children were tested on non-verbal IQ by means of the Ravens Progressive Matrices test, which is used in Iran to test non-verbal IQ level for children aged 5 to 9 . The average score of normal developing children of that age is $55 \%$. Table 4 presents the IQ scores of the ASD children who took part in our experiment; on the basis of that score they were further classified as high- or lowfunctioning (HFA and LFA respectively).

Table 3. Subjects

\begin{tabular}{llll}
\hline group & $\#$ & mean age & age range \\
\hline TD & 10 & $6 ; 2$ & $5 ; 6-6 ; 5$ \\
ASD & 10 & $8 ; 9$ & $5 ; 5-13 ; 0$ \\
adult & 10 & $27 ; 5$ & \\
\hline
\end{tabular}

Table 4. Details of the ASD subjects

\begin{tabular}{lllcll}
\hline participant & ASD classification & gender & age & raw score & percentage \\
\hline 1 & LFA & male & 5 & $7 / 36$ & $19.4 \%$ \\
2 & LFA & male & 6 & $2 / 9$ & $22.2 \%$ \\
3 & LFA & male & 8 & $5 / 18$ & $27 \%$ \\
4 & fFA & female & 12 & $2 / 9$ & $22.2 \%$ \\
5 & LFA & male & 13 & $5 / 36$ & $13.8 \%$ \\
6 & HFA & male & 6 & $5 / 12$ & $41.6 \%$ \\
7 & HFA & male & 10 & $1 / 2$ & $50 \%$ \\
8 & HFA & male & 12 & $3 / 4$ & $75 \%$ \\
9 & HFA & male & 6 & $13 / 36$ & $36 \%$ \\
10 & HFA & male & 8 & $4 / 9$ & $44 \%$ \\
\hline
\end{tabular}




\subsection{Procedure}

Children were tested individually in a quiet place in their schools. In the case of the subjects with ASD, testing was often (but not always) done in presence of their speech pathologist. The experiment was administered using a Macintosh Powerbook computer using Microsoft Power Point to show each slide, on which a sentence had been pre-recorded. If necessary, the experimenter repeated the sentence of the recorded voice. All subjects were given careful instructions before the experiment, and the actual experiment was preceded by an introduction to the characters depicted and two trial items. After hearing the experimental item, subjects had to identify a picture out of four in the screen, and thus the answers didn't require any verbal production. Children were encouraged after each item and after completing the test were given a small present.

\section{Results}

The results were coded as Target, Reverse, Other agent or No action (the three of them Non-Target). The statistical analysis of the results includes the descriptive statistics and a Logistic Regression model with repeated measures for the response variable Target result with covariates type of sentence and subject group. This analysis was performed with SAS software version 9.2 (SAS System, Cary, NC, USA, 2009).

The results considered come from the responses of the 30 subjects tested (adults, TD children and ASD children). Three subjects failed to answer all questions (low-functioning subjects 4 and 5 didn't answer 5 and 14 items respectively, and one TD child failed to answer one item). The results have therefore been computed on the basis of 1300 answers.

To exclude the possibility that children's performance may have been affected by fatigue, especially with the ASD population, we considered the results taking into account the order of presentation. No tendency was appreciated as an effect of order.

Adults performed at ceiling and the results for TD children appear in Table 5.

As we can see, although TD children are not at ceiling at ages 5-6, their performance is largely adult-like. If they produce any error, it is a reversal error (i.e. they take the subject to be the agent instead of the theme); this is the same error

Table 5. Mean performance in comprehension for TD children (in percentages; standard deviation in parenthesis)

\begin{tabular}{lllll}
\hline & target & reverse & other & no agent \\
\hline actives & $100 \%$ & 0 & 0 & 0 \\
short passives & $98 \%(4 \%)$ & $2 \%(4 \%)$ & 0 & 0 \\
long passives & $91 \%(12 \%)$ & $9 \%(12 \%)$ & 0 & 0 \\
\hline all sentences & $97 \%$ & $3 \%$ & 0 & 0 \\
\hline
\end{tabular}


that is typically found in child miscomprehension of passives, an error interpreted in Borer and Wexler (1992), Wexler (2004) as indicating the unergative interpretation of the passive.

Let us now turn to comprehension by ASD children. The results are presented in Tables 6 and 7.

To interpret the results, a Logistic Regression was modeled for the binary response variable Target result with the covariates subject type, sentence type and the interaction between the two.

For active Sentences, the Odds Ratio between TD and Low or High Functioning ASD (LFA and HFA respectively) can't be estimated because the TD subjects have a $100 \%$ Target results for active sentences. The Odds Ratio between HFA and LFA is $60.525, \mathrm{CI}_{95 \%}(\mathrm{OR})=(3.7,996.3)$, and it is statistically significant $(\mathrm{t}=4.56$; $\mathrm{p}$ value $=0.0002)$. Thus, a HFA subject has 61 times the odds of a LFA subject of having a Target result in active sentences. For short passive sentences, the Odds Ratio between LFA and TD is $0.011, \mathrm{CI}_{95 \%}(\mathrm{OR})=$ $(0,0.2)$, and it is statistically significant $(\mathrm{t}=-5.33$; $\mathrm{p}$-value $<0.0001)$. The Odds Ratio between HFA and LFA is $30.803, \mathrm{CI}_{95 \%}(\mathrm{OR})=(2.2,436.1)$, and it is statistically significant $(\mathrm{t}=4.02$; $\mathrm{p}$-value $=0.0020)$. Thus, a HFA subject has 31 times the odds of producing a correct answer that a LFA subject. For short passives, the Odds Ratio between HFA and TD is 0.325 , and it is not statistically significant. For long passive sentences, the Odds Ratio between LFA and TD individuals is $0.065, \mathrm{CI}_{95 \%}(\mathrm{OR})=(0,0.6)$, and it is statistically significant $(\mathrm{t}=-3.96$; $\mathrm{p}$-value $=0.0026)$. The differences for long passive comprehension between HFA and LFA and between HFA and TD are no statistically significant.

Table 6. Mean performance in comprehension for low-functioning ASD children (in percentages; standard deviation in parenthesis)

\begin{tabular}{lllll}
\hline & target & reverse & other & no agent \\
\hline actives & $56 \%(10 \%)$ & $31 \%(11 \%)$ & $10 \%(4 \%)$ & $2 \%(3 \%)$ \\
short passives & $40 \%(18 \%)$ & $46 \%(11 \%)$ & $5 \%(12 \%)$ & $9 \%(10 \%)$ \\
long passives & $51 \%(22 \%)$ & $27 \%(13 \%)$ & $18 \%(18 \%)$ & $4 \%(8 \%)$ \\
\hline all sentences & $51 \%$ & $34 \%$ & $12 \%$ & $4 \%$ \\
\hline
\end{tabular}

Table 7. Mean performance in comprehension for high-functioning ASD children (in percentages; standard deviation in parenthesis)

\begin{tabular}{lllll}
\hline & target & reverse & other & no agent \\
\hline actives & $97 \%(4 \%)$ & $1 \%(2 \%)$ & $1 \%(2 \%)$ & $1 \%(2 \%)$ \\
short passives & $91 \%(20 \%)$ & $9 \%(20 \%)$ & 0 & 0 \\
long passives & $76 \%(16 \%)$ & $20 \%(16 \%)$ & $4 \%(8 \%)$ & 0 \\
\hline all sentences & $90 \%$ & $8 \%$ & $1 \%$ & 0 \\
\hline
\end{tabular}


Considering now the results by sentence type, for LFA individuals there isn't any statistically significant Odds Ratio between sentence types. For HFA the Odds Ratio between Active and Long Passive Sentences is 14.974, $\mathrm{CI}_{95 \%}(\mathrm{OR})=(1.6,137.4)$, and it is statistically significant $(\mathrm{t}=3.8 ; \mathrm{p}$-value $=0.0049)$. Other Odds Ratios for HFA individuals are not statistically significant. For TD individuals, the Odds Ratio between Active and Long Passive or Short Passive can't be estimated because the TD subjects have $100 \%$ target results with active sentences. The Odds Ratio between long passives and short Passives is not statistically significant.

The results for the three sentence types are graphically represented in Figure 2.

Overall the picture that emerges is one in which TD and HFA perform equally when the comparison can be performed, i.e. in short and long passives. LFA are, in contrast, different from HFA in the comprehension of actives, short and long passives. Therefore, the divide is found between TD and HFA on the one hand and LFA on the other, rather than ASD children vs. TD. Moreover, the performance of the LFA children presents a pattern that bears no resemblance to that of TD children at any age: in the first place, not only they miscomprehend passives, but also actives. Second, the error pattern (represented in Figure 3) is also different because they produce a higher number of No agent and No action errors, not attested at all in the Persian TD children and only marginally in the HFA children. Still, reverse errors remain the most common for LFA children (31\% in active sentences, $46 \%$ in short passives, $27 \%$ in long passives).

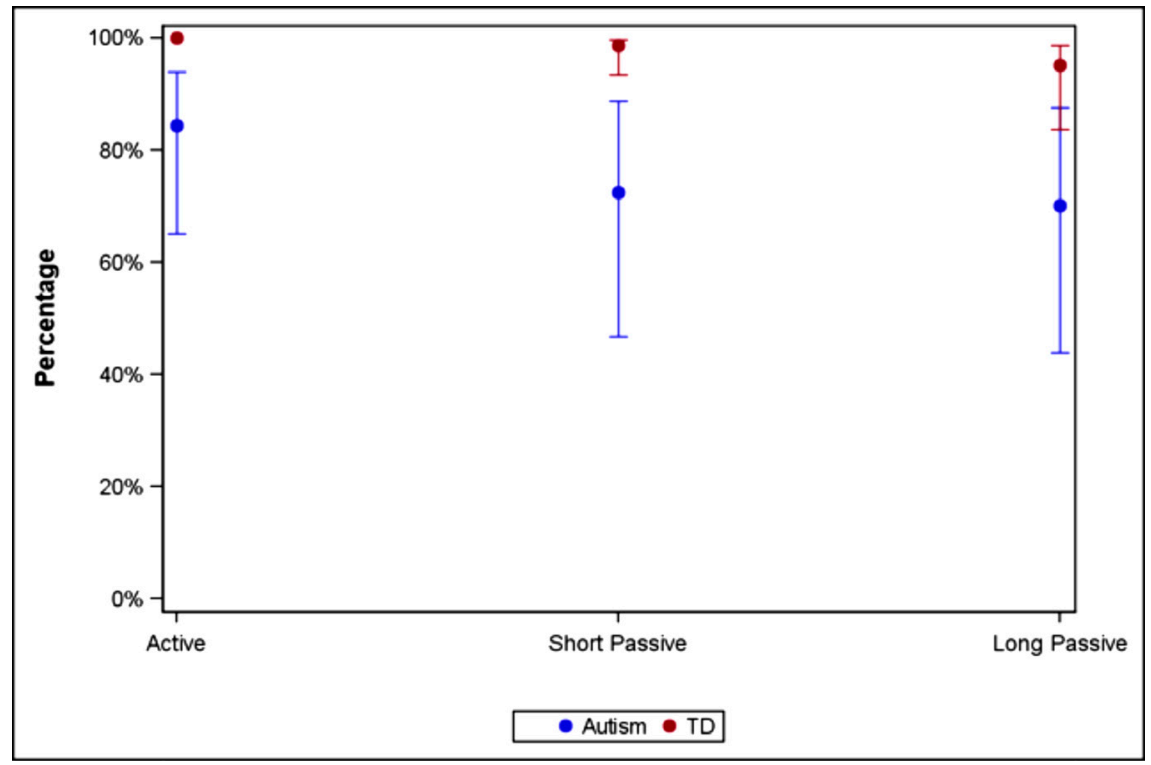

Figure 2. Percentage correct for the three populations tested. 


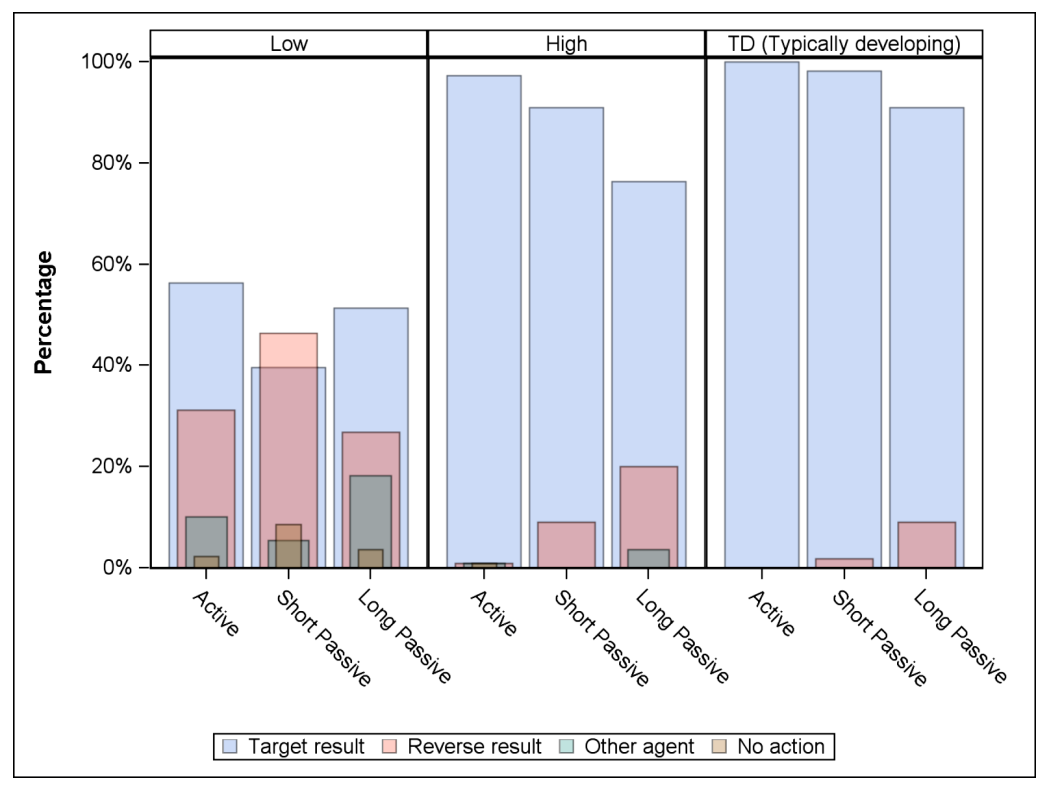

Figure 3. Results by type of answer for TD, HFA and LFA.

\section{How do these results compare with those in the literature?}

This in section we compare the results original to this paper with former results on (i) TD child performance in other languages and (ii) the performance of ASD children in the two languages previously investigated, English and Greek.

As mentioned earlier, there is no study of the acquisition of passives in TD Persian-speaking children. Since we used the same method and materials as ArmonLotem et al. (submitted), comparison should be straightforward. In Armon-Lotem et al. (submitted) ten languages were tested with 5-year-olds and the results showed better performance with short passives than long passives. Mean performance was $93.42 \%$ on short passives and $90.08 \%$ on long passives, to be compared to $98 \%$ and $91 \%$ in the Persian results here. Naturally, the performance for the languages tested by Armon-Lotem et al. (submitted) differed from one language to another; in Catalan, Dutch, German, Hebrew and Polish children performed significantly better with short passives than with long passives, while in English and Danish no such difference was found between the two passives. In none of the languages in Arnom-Lotem et al. (submitted) were the children at ceiling with actives (or short passives). The Persian children in our study were slightly older (the mean age in months in Armon-Lotem et al. submitted was 66 months, here it is 74 months). This difference in age may account for the ceiling performance in Persian actives and also for the accurate response to short passives. Briefly, the Persian results are in line with those in languages formerly investigated, and small differences may 
be attributed to a small age difference. At age 6 the comprehension of passives by Persian-speaking children is not entirely adult-like, as we expect if maturation is reached around six years and a half (Hirsch and Wexler 2006, Hirsch 2011). We would also expect 7-year-olds to be at ceiling, and younger children to miscomprehend passives at a higher rate -with errors of the Reverse type. This remains for future research.

Let us now compare the results for the ASD children to those available in the literature. Perovic et al. (2007) found that, for English, the mean score for actives was $78 \%$, for short passives $36 \%$ and for long passives $39 \%$ (we only take into account actional verbs, since only these have been tested in Persian). These results are poorer than those of our high-functioning individuals $(97 \%, 91 \%$ and $76 \%$ respectively); if we compare them to those of the low-functioning individuals, Persian subjects performed worse on actives (56\%) and similarly (although slightly better) on passives ( $40 \%$ and $51 \%$ on short and long passives respectively). The problem here is that we cannot access the low/high functioning categorisation of Perovic et al.'s subjects. ${ }^{5}$

For Greek, Terzi et al. (2014) only tested high functioning individuals, and those only for short passives. Mean performance was $66.6 \%$ correct, to be compared with $70 \%$ for TD children; on average these children performed worse than the Persian high functioning, but they were also younger. What is relevant here is that no difference emerged between the TD and the HFA in Greek, and none was found in Persian either. One respect in which the Greek and the Persian study vary is age: the Persian ASD subjects are older than the Greek -and for Persian we do not have results for an age-matched control group. With that proviso, our results are concordant with the Greek results, and indicate no maturational delay in the comprehension of verbal passive in high functioning ASD individuals.

There is no group of low functioning ASD children to compare ours with, except for an individual tested by Schroeder (2013); Schroeder conducted a study of ASD in Danish with the same experimental design as ours, and obtained similar results with HFA; the one LFA subject she tested performed poorly. Although this result should be taken with caution, it is indicative that HFA and LFA perform differently.

Judging by our sample, delay in the maturation of passives does not describe the group of LFA individuals, since they miscomprehend passives, but also actives. This could lead us to the same conclusion as in Perovic et al. (2007) that low functioning ASD subjects are not simply delayed, but impaired in their linguistic capacities (although Perovic and colleagues make that claim about all ASD children). Alternatively, there could be a different cognitive source for these results, related e.g. to short term memory. Non-verbal, cognitive abilities correlate with the performance of the Persian ASD children in our experiment and the reason why it should be so, under standard assumptions of the modularity of mind, remains for future research.

5. No standard deviation is provided in their results either and so we do not know if there was much variation amongst subjects. 


\section{References}

American Psychiatric Association (1994). Diagnostic and Statistical Manual of Mental Disorders (DSM-IV sourcebook), Vol. I, Washington, DC: American Psychiatric Association.

American Psychiatric Association (2000). Diagnostic and Statistical Manual of Mental Disorders (DSM-IV-TR) (4th ed., text revision). Washington, DC: American Psychiatric Association.

American Psychiatric Association (2013). Diagnostic and Statistical Manual of Mental Disorders (5 $5^{\text {th }}$ edition). Arlington, VA: American Psychiatric Publishing.

Armon Lotem, Sharon; Haman, Ewa; Jensen de López, Kristine M.; Smoczynska, Magdalena; Yatsushiro, Kazuko; Szczerbinski, Marcin; Dabasinskiene, Ineta; Gavarro, Anna; Hobbs, Erin; Kamandulyte, Laura; Katsos, Napoleon; Kunnari, Sari; Michaelidou, Chrisa; Sundahl Olsen, Lone; Parramon, Xavier; Sauerland, Uli; Torn-Leesik, Reeli; van der Lely, Heather; van Hout, Angeliek (submitted). «A large scale crosslinguistic investigation of the acquisition of passive». Ms.

Babyonyshev, Maria; Brun, Dina (2003). «The role of aspect in the acquisition of passive constructions in Russian». Paper presented at Generative Approaches to Language Acquisition - GALA 2003.

Babyonyshev, Maria; Ganger, Jennifer, Pesetsky, David, and Kenneth Wexler (2001). «The maturation of grammatical principles: evidence from Russian unaccusatives». Linguistic Inquiry, 32(1): 1-44.

Baron-Cohen, Simon (1989). «The autistic child's theory of mind: A case of specific developmental delay». Journal of Child Psychology and Psychiatry, 30(2): 285297.

Baron-Cohen, Simon; Tager-Flusberg, Helen; Cohen, Donald J. (2000). Understanding other minds: Perspectives from developmental cognitive neuroscience. Oxford/New York: Oxford University Press.

Bohnacker, Ute; Mohammadi, Somayeh (2012). «Acquiring Persian object marking: Balochi learners of L2 Persian». Orientalia Suecana, LXI: 59-89.

Borer, Hagit; Wexler, Ken (1992). «Bi-unique relations and the maturation of grammatical principles». Natural Language and Linguistic Theory, 10: 147-189.

Crawford, Jean (2008). «The long and short of it». Paper presented at the Boston University Conference on Language Development, BUCLD, Boston.

Demuth, Katherine; Moloi, Francina; Machobane, Malillo (2010). «Three-year-olds comprehension, production, and generalization of Sesotho passives». Cognition, 115(2): 238-251.

Family, Neiloufar (2009) «Lighten up: The acquisition of light verb constructions in Persian». In Chnadlee, Jane; Franchini, Michelle; Lord, Sandy; Rheiner, GudrunMarion (eds.) BUCLD 33: Proceedings of the 33rd annual Boston University Conference on Language Development. Somerville, MA: Cascadilla Press, pp. $139-150$.

Fox, Danny; Grodzinsky, Yosef (1998). «Children's passive: A view from the by phrase». Linguistic Inquiry, 29(2): 311-332.

Gavarró, Anna; Lewandowski, Wojciech; Markova, Angelina (2010). «An approach to multiple interrogatives in child Bulgarian and Polish». In Costa, Joao; Castro, Ana; Lobo, Maria; Pratas, Fernanda (eds.). Language Acquisition and Development Proceedings of GALA 2009. Newcastle: Cambridge Scholars Press, pp. 170-181. 
Grebenyova, Lydia (2011). «Acquisition of Multiple Questions in English, Russian and Malayalam». Language Acquisition, 18(3): 139-175.

Heshmati, Yalda (2013). Comprehension of passives in Persian speaking children with $A S D$ - An investigation of grammar in autism. UAB, MA dissertation.

Hirsch, Christopher (2011). The Acquisition of Raising. MIT, doctoral dissertation.

Hirsch, Christopher; Wexler, Ken (2006). «Children's passives and their resulting interpretation». In Deen, Kamil U., Nomura, Jun, Schultz, Barbara and Schwartz, Bonnie (eds.) The Proceedings of the Inaugural Conference on Generative Approaches to Language Acquisition -North America, University of Connecticut Occasional Papers in Linguistics, pp. 125-136.

Kanner, Leo (1943). «Autistic disturbances of affective contact». Nervous Child, 2(3): 217-250.

Karimi, Simin (1997). «Persian complex predicates and LF incorporation». Proceedings of the Chicago Linguistic Society (CLS), 33: 215-229.

Kjelgaard, Margaret M.; Tager-Flusberg, Helen (2001). «An investigation of language impairment in autism: Implications for genetic subgroups». Language and Cognitive Processes, 16(2-3): 287-308.

Khosravizadeh, Zahra; Mahabadi, Haghighi; Taghva, Firooz (2012). «An amazing conundrum in children's comprehension and production of verb inflection». World Applied Sciences Journal, 18(8): 1095-1101.

Lee, Anthony; Hobson, R. Peter; Chiat, Shulamuth (1994). «I, you, me, and autism: An experimental study». Journal of Autism and Developmental Disorders, 24: 155-176.

Leyfer, Ovsanna T., Tager-Flusberg, Helen, Dowd, Michael, Tomblin, J. Bruce, and Folstein, Susan E. (2008). «Overlap between autism and specific language impairment: Comparison of autism diagnostic interview and autism diagnostic observation schedule scores». Autism Research, 1(5): 284-296.

Lord, Catherine; Risi, Susan; Lambrecht, Linda; Cook, Edwin H.; Leventhal, Bennett L.; DiLavore, Pamela C; Pickles, Andrew; Rutter, Michael (2000). «The autism diagnostic observation schedule-generic: a standard measure of social and communication deficits associated with the spectrum of autism». Journal of Autism and Developmental Disorders, 30: 205-223.

Maratsos, Michael; Fox, Dana E.; Becker, Judith A.; and Chalkley, Mary Anne (1985). «Semantic restrictions on children's passives». Cognition, 19(2): 167-191.

McCann, Joanne; Peppé, Sue (2003). «Prosody and autistic spectrum disorders: A critical review». International Journal of Language and Communication Disorders, 38: $325-350$.

Nemati, Fatemeh (2013). «On the syntax-semantics of passives in Persian». In: Alexiadou, Artemis; Schäfer, Florian (eds.). Non-Canonical Passives. Amsterdam/ Philadelphia: John Benjamins, pp. 261-280.

O’Brien, Karen; Grolla, Elaine; Lillo-Martin, Diane (2006). «Long passives are understood by young children». In: Banmas, David; Magnitskaia, Tatiana; Zaller, Colleen (eds.). BUCLD 30: Proceedings of the 30th annual Boston University Conference on Language Development. Somerville, MA: Cascadilla Press, pp. 441-451.

Orfitelli, Robyn (2012). Argument Intervention in the Acquisition of A-movement. UCLA, doctoral dissertation.

Parramon, Xavier (2009). The acquisition of actional passives in Catalan. UAB, MA dissertation. 
Paul, Daniel (2004). «The passive in Persian». SOAS Working Papers in Linguistics, 13: 221-235.

Perovic, Alexandra (2006). «Syntactic deficit in Down syndrome: More evidence for the modular organization of language». Lingua, 116(10): 1616-1630.

Perovic, Alexandra; Modyanova, Nadya; Hanson, Ellen; Nelson, Charles; Wexler, Ken (2007). «Investigations of language in autism: Evidence for a grammatical deficiency». Poster presented at Autism Research in the UK: From Diagnosis to Intervention, The Open University.

Perovic, Alexandra; Modyanova, Nadya; Wexler, Ken (2007). «Knowledge of c-command and A-movement in children and adolescents with autism and Asperger syndrome». Paper presented at Generative Approaches to Language Acquisition, GALA 2007.

Perovic, Alexandra; Modyanova, Nadya; Wexler, Ken (2013). «Comprehension of reflexive and personal pronouns in children with autism: A syntactic or pragmatic deficit?». Applied Psycholinguistics, 20(2): 1-23.

Perovic, Alexandra; Wexler, Ken (2010). «Development of verbal passive in Williams syndrome». Journal of Speech, Language and Hearing Research, 53: 1294-1306.

Pierce, Amy (1992). «The acquisition of passives in Spanish and the question of A-chain maturation». Language Acquisition, 2(1): 55-81.

Schroeder, K. (2013). What Was Done to Whom? Passive Voice Comprehension in High-Functioning Danish Autistics. UAB, MA dissertation.

Sugisaki, Koji (1999). «Japanese Passives in Acquisition». In: Braze, David; Hiramatsu, Kazuko; Kudo, Yutaka (eds.) Cranberry Linguistics: University of Connecticut Working Papers in Linguistics, 10: 145-156.

Tager-Flusberg, Helen (1981). «On the nature of linguistic functioning in early infantile autism». Journal of Autism and Developmental Disorders, 11(1): 45-56.

Tager-Flusberg, Helen (1991). «Semantic processing in the free recall of autistic children: Further evidence for a cognitive deficit». British Journal of Developmental Psychology, 9(3): 417-430.

Tager-Flusberg, Helen (2001). «A re-examination of the theory of mind hypothesis of autism». In: Burack, Jacob; Charman, Tony; Yirmiya, Nurit; Zelazo, Philip R. (eds.) Development in Autism: Perspectives from Theory and Research, Hillsdale, NJ: Erlbaum, pp. 173-193.

Terzi, Arhonto; Marinis, Theodoros; Kotsopoulou, Angeliki; Francis, Konstantinos (2014). «Grammatical abilities of Greek-speaking children with autism». Language Acquisition, 21(1): 4-44.

Terzi, Arhonto; Wexler, Ken (2002). «A-chains and s-homophones in children's grammar: evidence from Greek passives». In: Hirotani, Masako (ed.). Proceedings of the 32nd North Eastern Linguistic Society [NELS 32]. New York: The City University of New York and New York University, pp. 519-537.

Verrips, M. (1996). Potatoes must peel: The acquisition of the Dutch passive. University of Amsterdam, doctoral dissertation.

Wexler, Ken (2004). «Theory of phasal development: Perfection in child grammar». MIT Working Papers in Linguistics, 48: 159-209.

Zare, Ameneh; Nematzadeh, Shahin; Raghibdoust, Shahla; Kalbassi, Iran (2012). «Autistic children and different tense forms». World Academy of Sciences, Engineering and Technology, 70: 73-76. 


\section{Appendix: Experimental items (in order of presentation)}

1. Dokhtær-e bozorg dokhtær-e koochæk ra hol mi-dæhæd. 'The big girl is pushing little girl.'

2. Dokhtær-e bozorg dokhtær-e koochæk ra moayene mi-konæd. 'The big girl is examining the little girl'

3. Dokhtær-e koochæk tævæsote madær boosid-eh mi-šævæd. 'The little girl is kissed by mom'

4. Madær tævæsote dokhtær-e bozorg donbal mi-šævæd. 'Mom is chased by the big girl.'

5. Madær mooha-e madærbozorg ra šane mi-konæd. 'Mom is combing grandma.'

6. Dokhtær-e koochæk madærbozorg ra nævazeš mi-konæd 'The little girl is stroking grandma.'

7. Dokhtær-e bozorg tævæsote dokhtære koochæk hol dad-eh mi-šævæd. 'The big girl is pushed by the little girl.'

8. Dokhtær-e bozorg tævæsote dokhtære koochæk moayen-eh mi-šævæd. 'The big girl is examined by the little girl.'

9. Dokhtær-e koochæk madær ra mi-boosæd. 'The little girl is kissing mom.'

10. Mædær dokhtær-e bozorg ra donbal mi-konæd 'Mom is chasing the big girl.'

11. Mooha-e madær tævæsote madærbozorg šane mi-šævæd. 'Mom is combed by grandma.'

12. Madær tævæsote dokhtær-e bozorg næghaši mi-šævæd 'Mom is drawn by the big girl.'

13. Dokhtær-e koochæk dokhtær-ez bozorg ra hol mi-dæhæd. 'The little girl is pushing the big girl.'

14. Dokhtær -e koochæk dokhtær-e bozorg ra moayene mi-konæd. 'The little girl is examining the big girl.'

15. Madær boosid-eh mi- šævæd. 'Mom is kissed.'

16. Dokhtære bozorg donbal mi-šævæd. 'The big girl is chased.'

17. Madærbozorg mooha-e madær ra šane mi-konæd. 'Grandma is combing mom.'

18. Dokhtær-e bozorg madær ra næghaši mi-konæd. 'The big girl is drawing mom.'

19. Madærbozorg dokhtær-e koochæk ra nævazeš mi-konæd. 'Grandma is stroking the little girl.'

20. Dokhtær-e koochæk hol dad-eh mi-šævæd. 'The little girl is pushed.'

21. Dokhtær-e koochæk moayen-eh mi-šævæd 'The little girl is examined.'

22. Madær dokhtær-e koochæk ra mi-boosad. 'Mom is kissing the little girl.' 
23. Dokthar-e bozorg madær ra donbal mi-konæd.

'The big girl is chasing mom.'

24. Mooha-e madærbozorg šane mi-šævæd.

'Grandma is combed.'

25. Dokhtær-e bozorg næghaši mi-šævæd.

'The big girl is drawn.'

26. Madærbozorg nævazeš mi-šævæd.

'Grandma is stroked.'

27. Pesære koochæk pedærbozorg ra bæghal mi-konæd.

'The little boy is hugging grandpa.'

28. Pesære koochæk tavasote pedær poošand-eh mi-šævæd

'The little boy is covered by dad.'

29. Pesær-e bozorg pesær-e koochæk ra hæml mi-konæd.

'The big boy is carrying the little boy.'

30. Pedarbozorg riš-e pedær ra eslah mi-konæd.

'Grandpa is shaving dad.'

31. Pesær-e koochæk sooræt-e pedær ra næghaši mi-konæd

'The little boy is face-painted by dad.'

32. Pesær-e koochæk tavasote pedærbozorg bæghal mi-šævæd

'The little boy is hugged by grandpa.'

33. Pesære koochæk pedær ra mi-poošanad.

'The little boy is covering dad.'

34. Pesære bozorg tavasote pesære koochæk hæml mišævæd

'The big boy is carried by the little boy.'

35 Riš-e pedærbozorg tavasote pedær eslah mi-šævæd

'Grandpa is shaved by dad.'

36. Sooræt-e pesære koochæk næghaši mi-šævæd.

'The little boy is face-painting dad.'

37. Pedær poošandeh mi-šævæd

'Dad is covered.'

38. Pesære koochæk pesære bozorg ra hæml mi-konæd.

'The little boy is carrying the big boy.'

39. Pedær rišs-e pedærbozorg ra eslah mi-konæd.

'Dad is shaving grandpa.'

40. Sooræt-eh pedær næghaši mi-šævæd

'Dad is face-painted.'

41. Pedær pesær-e koochæk ra mi-poošanad.

'Dad is covering the little boy.'

42. Pesær-e koochæk hæml mi-šævæd.

'The little boy is carried.'

43. Riš-eh pedær eslah mi-šævæd

'Dad is shaved.'

44. Pedær sooræt-e pesære koochæk ra næghaši mikonæd.

'Dad is face-painting the little boy.' 